\title{
Communication
}

\section{Genetic diversity among red mombin fruits in the Southwest of Goiás ${ }^{1}$}

\author{
Laísse Danielle Pereira 2 , Lasara Kamila Ferreira de Souza $a^{3}$, Karminne Dias do Valle, \\ Francielly Rodrigues Gomes ${ }^{3 *} \mathbb{D}$, Jefferson Fernando Naves Pinto ${ }^{3}$, Danielle Fabiola Pereira da Silva ${ }^{3}$
}

10.1590/0034-737X201966020010

\begin{abstract}
The identification of productive plants with fruits of desirable characteristics contributes to the optimization of commercial crops of red mombin fruits. The aim of this work was to evaluate the genetic diversity among the provenance of red mombin of two municipalities of the state of Goiás. The fruits were harvested at ripening stage 3 and transported to the laboratory. The treatments were composed of fruits harvested from three plants, being ten repetitions and five fruits per experimental plot, totaling fifty fruits per provenance. Considering each repetition as an individual, 15 individuals were evaluated for length, diameter, weight, color attributes of the pericarp and pulp, soluble solids content and titratable acidity of the pulp, ratio of soluble solids content and acidity, and vitamin C content of the pulp. The results were subjected to descriptive analysis. A multivariate analysis was performed estimating the mean Euclidean distance obtained from the provenances, based on the attributes of the fruits analyzed. The measure of similarity and grouping of the provenances were done through the Tocher optimization algorithm and UPGMA dendrogram. The variables contributed similarly to dissimilarity. The Tocher method grouped the individuals into four groups, while in the UPGMA dendrogram, seven groups were formed.
\end{abstract}

Keywords: Spondias purpurea L.; fruit quality; multivariate analysis.

\section{INTRODUCTION}

The fruit trees of the Brazilian Savanna are very rich from a nutritional and functional point of view, presenting sensory properties such as color, flavor, and a very pleasant aroma. According to Negri et al. (2016), the consumption of antioxidants helps protect against oxidative damage and reduces the risks of cardiovascular diseases, in which vitamins, phenolic compounds, and carotenoids a major source of antioxidants.

Due to these factors, those fruits have great popular acceptance and are consumed traditionally in natura or in the form of ice cream, jellies, candies, and juices. There are approximately 71 fruit species with economic potential in the Brazilian Savanna (Agostini-Costa et al., 2010), among them, the fruits of red mombin occupy a prominent place in several regions.
The red mombin tree (Spondias purpurea L.) is originated in Tropical America (Maldonado-Astudillo et al., 2014) and produces fruits with variable size and weight, whose epicarp shows red coloration when mature (Vargas et al., 2017); however, there is a scarcity of scientific data especially regarding its genetic diversity (Silva et al., 2012).

The study of genetic diversity allows to group the genotypes through multivariate techniques and is an efficient way of identifying the genetically different or promising genotypes (Godoy et al., 2006; Cruz et al., 2011) seeking to minimize the variation within the groups and to maximize the variation between the groups (Rodrigues et al., 2017).

These studies are essential to support breeding programs and management of plant resources, as well as to map conservation strategies on a regional or geographical scale (Cruz et al., 2011).

\footnotetext{
Submitted on Octuber 21st, 2018 and accepted on March 08 $8^{\text {th }}, 2019$.

${ }^{1}$ This work had financial support of CAPES and CNPq.

${ }^{2}$ Instituto Federal Goiano, Campus Rio Verde, Goiás, Brazil. laissedaniellep@gmail.com

3Universidade Federal de Jataí, Unidade Acadêmica Especial de Ciências Agrárias, Jataí, Goiás, Brazil. engekah.lk@gmail.com; karminnevalle@gmail.com; fram_rodgomes@hotmail.com; jeffnaves@gmail.com; daniellefpsilva@gmail.com

*Corresponding author: fram_rodgomes@hotmail.com
} 
The importance of knowing the genetic diversity is given by the possibility of establishing cultivation recommendations (Monteiro et al., 2009). Due to the low costs of accomplishment, these studies have been extensively performed in perennial plants based on agronomic, botanical, and morphological descriptors (Silva et al., 2014).

The objective of this work was to evaluate the genetic diversity among the sources of red mombin fruits from three locations of Savanna, considering the most important characteristics in the evaluation of the genetic diversity of fruit quality traits based on multivariate procedures.

\section{MATERIALAND METHODS}

The fruits were collected in a circular area located under the canopy of the plant. This area was imaginatively divided into four quadrants by two lines perpendicular to each other, forming a cartesian plan originated in the trunk of the tree, and from each quadrant, 25 fruits of red mombin were collected, totalling 100 fruits per plant.

After harvest, fruits were packed in low-density polyethylene bags and transported to the laboratory, where they were selected for the absence of mechanical injury and pathogen attack.

The treatments consisted of fruits harvested in different provenances of the state, being 10 repetitions and 10 fruits per experimental plot, totaling 100 fruits per origin. Considering each repetition as an individual, there was a total of 30 individuals (Table 1). Fruits were harvested at ripening stage 3 , which is characterized predominantly by the red or yellow epidermis (Chitarra \& Chitarra, 2005).

Fruits were evaluated for length, diameter, weight, color attributes of the pericarp and pulp, soluble solids content, titratable acidity of the pulp, ratio between soluble solids content and acidity, and vitamin $\mathrm{C}$ content of the pulp. The weight measurements (expressed in grams) of the fruits were obtained through a digital scale. The length and diameter (in millimeters) of the fruits were determined using a caliper.

The color of the pericarp and pulp was given by the coordinate $\mathrm{C}^{*}$ and angle Hue $\left(\mathrm{h}^{\circ}\right)$, determined by using a Konica Minolta ${ }^{\circledR}$ colorimeter, model CR-10, which measures the reflected light using a cartesian coordinate system $\mathrm{L}^{*}, \mathrm{a}^{*}$, and $\mathrm{b}^{*}$. Through these coordinates, we obtained units or points of approximate visual uniformity.

Table 1: Identification of the red mombin provenances and the respective municipalities of collection

\begin{tabular}{lcc}
\hline County & Municipality & Identification \\
\hline Provenance 1 & Jataí - GO & J1 to J5 \\
Provenance 2 & Jataí - GO & J6 to J10 \\
Provenance 3 & Montividiu - GO & M11 to M15 \\
\hline
\end{tabular}

Value $\mathrm{a}^{*}$ corresponds to the red-green scale and ranges from +60 to " 60 , with negative values corresponding to different shades of green and positive values, to shades of red. Parameter $b^{*}$ corresponds to the yellow-blue scale and also varies from +60 to " 60 , with negative values corresponding to blue tones and positive values, to yellow tones. Parameter L* refers to the brightness level, ranging from 0 (black) to 100 (white).

Fruits were analyzed for soluble solids content (SS) using a portable refractometer, and the results were expressed in ${ }^{\circ}$ Brix.

The results were submitted to descriptive analysis and the mean, minimum, and maximum values, coefficient of variation $(\mathrm{CV})$, variance, standard deviation, as well as the relative contribution $(\mathrm{Sj})$ of the 10 variables by the Singh method (1981) were obtained.

Multivariate analysis was used to estimate the mean Euclidean distance obtained from the three collection environments, evaluated based on the attributes of the fruits analyzed. The measurement of similarity and clustering of the collection environments was done by Tocher's optimization algorithm and UPGMA(Unweighted Pair Group Method using Arithmetic Averages) dendrogram (Cruz et al., 2012).

The cut-off criterion used to determine the number of groups in the UPGMA method was based on the relative size of the three levels of fusions (distances). The cophenetic correlation coefficient was calculated between the genetic dissimilarity matrix and the matrix of the cophenetic values to verify the consistency of the cluster.

Data analysis was performed with the GENES computer program (Cruz, 2013). The dendrogram was made using Statistic ${ }^{\circledR}$ software version 5.0.

\section{RESULTS AND DISCUSSION}

The contribution of the variables to genetic dissimilarity among the red mombin individuals was relatively well distributed, ranging from 5.33 to $13.92 \%$ (Table 2). The variables that contributed the most to the divergence of the populations and formation of groups by the clustering methods were the epidermal coordinate $\mathrm{b}$ $(13,92 \%)$ and the epidermal coordinate $\mathrm{C}(13.10 \%)$, while the SS was the variable that contributed the least (5.33\%).

The $\mathrm{Sj}$ indicates which variables can be excluded in future studies, considering that the most important traits express greater variability; on the other hand, those of smaller importance express less variability, allowing their disposal (Singh, 1981). However, since there were no major differences between the values in the present study, no trait can be eliminated.

Soluble solids content presented an average value of $13.93{ }^{\circ}$ Brix and a CV of $5.35 \%$, demonstrating its low 
variability among the fruits of the three provenances. Rocha et al. (2016), observed higher SS values (16.03 ${ }^{\circ}$ Brix), but with a CV lower than the value obtained in this study (1.55\%). The SS found by Giles et al. (2016), in the state of Espírito Santo was also higher than the values observed in the present study $\left(16.04{ }^{\circ} \mathrm{Brix}\right)$; however, with a $\mathrm{CV}$ of $10.56 \%$, higher than the value obtained in this experiment.

The coordinates $\mathrm{b}, \mathrm{C}$, and $\mathrm{h}$ of the epidermis presented CV of $78.49,47.66$, and $44.18 \%$, respectively. These values represent the high dispersion of the data in relation to the means, indicating that there was great variability among the colorations of the epidermis of the fruits from the three provenances. The coloration of the fruit epidermis can be influenced by factors such as soil, cultivar, and climatic conditions during fruit development, including solar incidence (Cremasco et al., 2016).

In a study with red mombin fruits in cities of northern Espírito Santo, Rocha et al. (2016), evaluating diversity based on the variables mass of the pulp, fruit mass, soluble solids, titratable acidity, ratio, polar and equatorial diameters, and the relationship between them and pulp yield, observed that the variables that contributed the most to the population discrimination and group formation were the mass of the pulp (39.65\%) and mass of the pulp fruit $(31.67 \%)$, while the lowest contribution was given by the pulp yield variable $(0.07 \%)$. In the present study, regardless of the variables related to color of the pulp and epidermis, the variable that contributed the most to the variation was weight (11.54\%), corroborating the work mentioned above.

The individuals were divided into four groups according to the grouping by the Tocher optimization method, which used the mean Euclidean distance for the 10 characteristics as a measure of dissimilarity (Table 3). This method is an optimization technique that separates the individuals into groups, maintaining the criterion that the distances within the groups are always smaller than the distances between the groups (Cruz et al., 2011).
Group 1 contained the largest number of individuals (J2, J3, J5, M13, M12, and J4), indicating that these individuals have common characteristics. Therefore, different characteristics are also expected in the other groups, in which the individuals were arranged as follows: group 2 (J6, J10, J8, J7, and J9), group 3 (M11, M15, and M14), and group 4 (J1). It is possible to notice that each group was formed exclusively by individuals from the same source.

Although plants from the same site remained in the same group, group 1 presented plants from different sites. Thus, it is possible to consider the occurrence of diversity among individuals of different origins and among individuals from the same place.

Using the UPGMA clustering method, considering the cut-off point of $16.64 \%$ of distance and using the Mojema criterion (1977), the 15 individuals were divided into seven groups of genetic similarity (Figure 1). In the first group were the individuals $\mathrm{J} 2, \mathrm{~J} 3, \mathrm{~J} 5$, and $\mathrm{J} 4$; in the second group, M12 and M13; in the third group, only J1; in the fourth group, M11 and M15; in the fifth group, M14; in the sixth group, J6, J10, J7, and J8; and in the seventh group, J9.

The grouping provided by this method was adequate to represent the genetic divergence and the formation of groups among the populations used for presenting the cophenetic correlation coefficient (CCC) of 0.87 . This coefficient is responsible for measuring the fit between the dissimilarity matrix and the simplification matrix due to

Table 3: Groups established by the Tocher method based on the 10 characteristics for the three provenances of red mombin

\begin{tabular}{lllllll}
\hline Group & \multicolumn{5}{c}{ Individual } \\
\hline 1 & J2 & J3 & J5 & M13 & M12 & J4 \\
2 & & J6 & J10 & J8 & J7 & J9 \\
3 & \multicolumn{4}{c}{ M11 } & M15 & M14 \\
4 & & \multicolumn{5}{c}{ J1 } \\
\hline
\end{tabular}

Table 2: Descriptive analysis and relative contribution $(\mathrm{Sj})$ of the 10 variables for the dissimilarity of the three provenances of red mombin

\begin{tabular}{lccccccc}
\hline Trait & Average & Minimum & Maximum & $\mathbf{C V}(\boldsymbol{\%})$ & Variance & SD & Sj $(\%)$ \\
\hline Length & 36.42 & 32.94 & 39.04 & 6.13 & 4.90 & 2.23 & 11.09 \\
Diameter & 28.70 & 25.15 & 32.17 & 8.87 & 6.49 & 2.54 & 10.92 \\
Weight & 18.74 & 12.00 & 23.9 & 23.68 & 19.69 & 4.43 & 11.54 \\
CbE & 17.42 & 5.03 & 38.42 & 78.49 & 187.07 & 13.67 & 13.92 \\
CCE & 25.69 & 13.26 & 44.08 & 47.66 & 149.93 & 12.24 & 13.10 \\
ChE & 38.67 & 18.33 & 67.38 & 44.18 & 291.86 & 17.08 & 10.06 \\
CbP & 23.35 & 17.34 & 29.48 & 15.56 & 13.21 & 3.63 & 7.44 \\
CCP & 24.14 & 17.46 & 29.41 & 16.77 & 16.40 & 4.05 & 9.53 \\
ChP & 81.11 & 75.45 & 90.53 & 5.412 & 19.27 & 4.38 & 7.032 \\
SS & 13.93 & 12.65 & 15.59 & 5.35 & 0.55 & 0.74 & 5.33 \\
\hline
\end{tabular}

$\mathrm{CbE}$ : coordinate $\mathrm{b}$ of the epidermis; CCE: coordinate $\mathrm{C}$ of the epidermis; ChE: coordinate $\mathrm{h}$ of the epidermis; CbP: coordinate $\mathrm{b}$ of the pulp; CCP: coordinate $\mathrm{C}$ of the pulp; ChP: coordinate h of the pulp; SS: soluble solids content. 


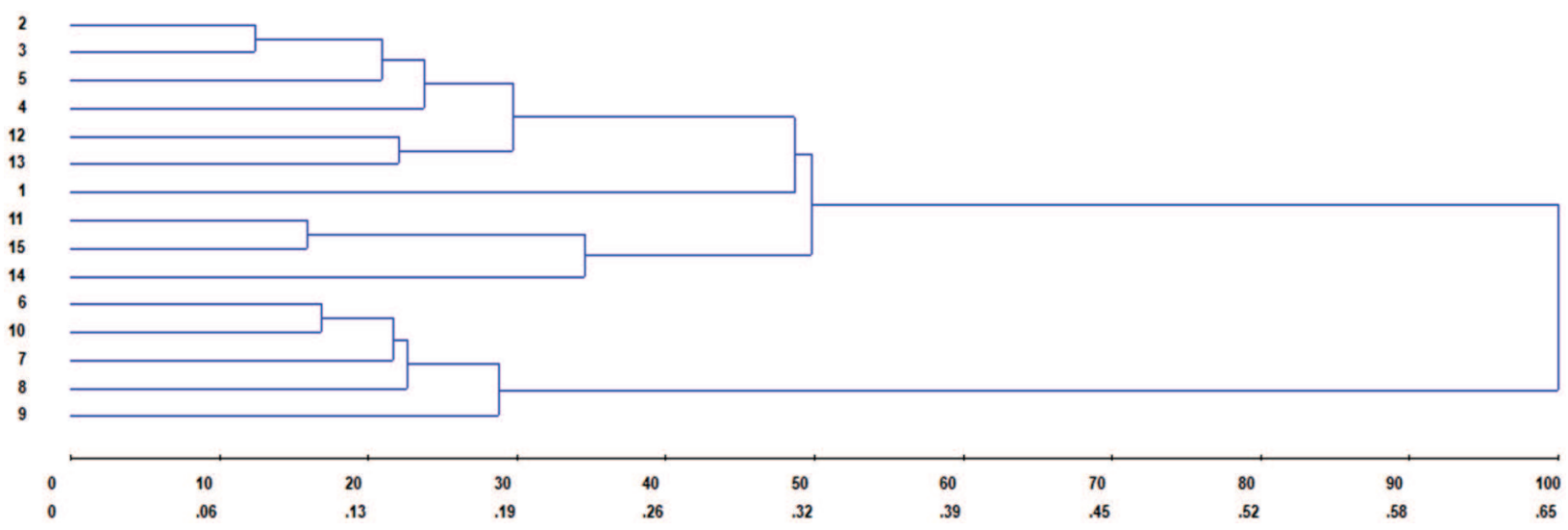

Figure 1: Dendrogram generated by the UPGMA method from dissimilarities expressed by mean Euclidean distance between three provenances of red mombin, considering 10 physical characteristics of fruits. Cophenetic Correlation Coefficient (CCC): 0.87.

the grouping method and can be used to increase the reliability of the conclusions regarding the interpretation of dendrograms (Cruz et al., 2012). Values of CCC above 0.80 indicate good representativity between distances (Cruz $\&$ Sheep, 2013).

Both methods (Tocher and UPGMA) were partially concordant with respect to the genetic divergence of individuals among themselves and among provenances. In the UPGMA, more groups were formed, not grouping individuals of different origins into the same group, differently from what occurred in group 1 of the Tocher method.

The grouping methods are differentiated by the type of result and by the different ways of defining the proximity between individuals or groups formed by these individuals. In all cases, the number of groups to be established is not known at first, and this provides different results (Rodrigues et al., 2010).

This high diversity provides subsidies for studies involving selection of materials with desirable agronomic characteristics. In addition, such diversity opens up good prospects for further studies on the potential of this fruit for commercial cultivation.

According to Lima et al. (2011), the knowledge about the genetic variability of a species is an essential requirement for its preservation and the success of breeding programs, since these studies provide parameters for the identification of parents to obtain segregating populations in breeding programs and to obtain genetically improved populations (Costa et al., 2006).

\section{CONCLUSIONS}

There is genetic diversity among the individuals of red mombin (Spondias purpurea L.), in which individual $\mathrm{J} 1$ is presented as the most divergent.

The coloration of the epidermis presented the most important relative contribution.
The variables contributed similarly to dissimilarity.

The Tocher method grouped the individuals into four groups, while the UPGMA dendrogram formed seven groups.

\section{ACKNOWLEDGEMENTS, FINANCIAL SUPPORT, AND FULL DISCLOSURE}

The authors thank the Coordination for the Improvement of Higher Education Personnel (CAPES) and National Council for Scientific and Technological Development $(\mathrm{CNPq})$, for the financial support.

\section{REFERENCES}

Agostini-Costa TS, Silva DB, Vieira RF, Sano SM \& Ferreira FR (2010) Espécies de maior relevância para a região Centro-Oeste. In: Vieira RF, Agostini-Costa TS, Silva DB, Sano S \& Ferreira FR (Ed.) Frutas nativas da região centro-oeste. Brasília, Embrapa. p.15-30.

Costa MN, Pereira WE, Bruno RLA, Freire EC, Nóbrega MBM, Milani M \& Oliveira AP (2006) Diversidade genética entre acessos e cultivares de mamoneira por meio de estatística multivariada. Pesquisa Agropecuária Brasileira, 41:1617-1622.

Chitarra MIF \& Chitarra AB (2005) Pós-colheita de frutas e hortaliças: fisiologia e manuseio. $2^{\mathrm{a}}$ ed. Lavras, Universidade Federal De Lavras. 785p.

Cremasco JPG, Matias RGP, Silva DFP, Oliveira JAA \& Bruckner CH (2016) Qualidade pós-colheita de oito variedades de pêssego. Comunicata Scientiae, 07:334-342.

Cruz CD (2013) GENES - a software package for analysis in experimental statistics and quantitative genetics. Acta Scientiarium 35:271-276.

Cruz CD, Ferreira FM \& Pessoni LA (2011) Biometria aplicada ao estudo da diversidade genética. Visconde do Rio Branco, Suprema. 620p

Cruz CD, Regazzi AJ \& Carneiro PCS (2012) Modelos biométricos aplicados ao melhoramento genético. $4^{\mathrm{a}}$ ed. Viçosa, UFV. 514p.

Giles JAD, Oliari LSO, Rocha ACB, Schmildt ER, Silva W \& França JM (2016) Correlações entre características físicas, químicas e físicoquímicas de frutos de cirigueleira. Revista Agro@mbiente On-line, 10:30-35. 
Godoy CV, Koga LJ \& Canteri MG (2006) Diagrammatic scale for assessment of soybean rust severity. Fitopatologia Brasileira, 31:63-68.

Lima ATB, Souza VAB, Gomes RLF \& Lima PSC (2011) Molecular characterization of cajá, Spondias mombin (Anacardiaceae) by RAPD markers. Genetics and Molecular Research, 10:28932904.

Maldonado-Astudillo YI, Alia-Tejacal I, Núñez-Colín CA, JiménezHernández J, Pelayo-Zaldívar C, López-Martínez V, AndradeRodríguez M, Bautista-Baños S \& Valle-Guadarrama S (2014) Postharvest physiology and technology of Spondias purpurea L. and S. mombin L. Scientia Horticulturae, 174:193-206.

Mojema R (1977) Hierarquial grouping methods and stopping rules: an evaluation. The Computer Journal, 20:359-363.

Monteiro ER, Bastos EM, Lopes ÂCA, Gomes RLF \& Nunes JAR (2009) Diversidade genética entre acessos de espécies cultivadas de pimentas. Ciência Rural, 40:288-283.

Negri TC, Berni P \& Brazaca S (2016) Valor nutricional de frutas nativas e exóticas do Brasil. Biosaúde, 18:82-96.

Rocha ACB, Oliari LS, Simão LA, França JM, Giles JAD, Silva W, Schmildt ER \& Schmildt O (2016) Divergência genética de ciriguela do norte do Espírito Santo. Nucleus, 13:143-152.

Rodrigues DL, Viana AP, Vieira HD, Santos EA, Lima FH \& Santos CL (2017) Contribuição de variáveis de produção e de semente para a divergência genética em maracujazeiro-azedo sob diferentes disponibilidades de nutrientes. Pesquisa Agropecuária Brasileira, 52:607-614
Rodrigues HCA, Rodrigues SR, Oliveira Junior O, Ceccon G, Correa AM \& Abot AR (2010) Avaliação da diversidade genética entre acessos de mamoneira (Ricinus communis L.) por meio de caracteres morfoagronômicos. Revista Ceres, 57:773-777.

Silva QJ, Moreira ACCG, Melo EA \& Lima VLAG (2012) Compostos fenólicos e atividade antioxidante de genótipos de ciriguelas (Spondia purpurea L.). Alimentos e Nutrição, 23:7380 .

Silva JOC, Cremasco JPG, Matias RGP, Silva DFP, Salazar AH \& Bruckner CH (2014) Divergência genética entre populações de pessegueiro baseada em características da planta e do fruto. Ciência Rural, 44:1770-1775.

Singh D (1981) The relative importance of characters affecting genetic divergence. Indian Journal of Genetic and Plant Breeding, 41:237-245

Vargas AS, Juárez-López P, López-Martínez V, Flores LJP, Sánchez DG \& Alia-Tejacal I (2017) Botânica e fisiologia/botany and physiology antioxidant activity and physicochemical parameters in 'cuernavaqueña'mexican plum (Spondias purpurea L.) at different ripening stages. Revista Brasileira de Fruticultura, 39:e787. 